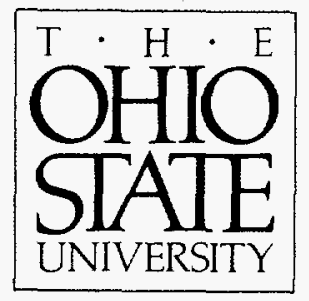

\title{
Pack Cementation Diffusion Coatings For Iron-Base Alloys
}

February 1995

Research sponsored by the U.S. Department of Energy, Fossil Energy Advanced Research and Technology Development Materials Program

Report prepared by

Robert A. Rapp

Department of Materials Science and Engineering

The Ohio State University

Columbus, Ohio 43210

under

Subcontract No. 19X-SB154C

for

OAK RIDGE NATIONAL LABORATORY

Oak Ridge, Tennessee 37831

managed by

MARTIN MARIETTA ENERGY SYSTEMS, INC.

for the

U.S. Department of Energy

under Contract No. DE-AC05-84OR21400

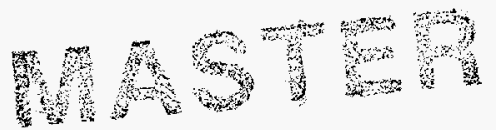




\section{DISCLAIMER}

This report was prepared as an account of work sponsored by an agency of the United States Government. Neither the United States Government nor any agency thereof, nor any of their employees, make any warranty, express or implied, or assumes any legal liability or responsibility for the accuracy, completeness, or usefulness of any information, apparatus, product, or process disclosed, or represents that its use would not infringe privately owned rights. Reference herein to any specific commercial product, process, or service by trade name, trademark, manufacturer, or otherwise does not necessarily constitute or imply its endorsement, recommendation, or favoring by the United States Government or any agency thereof. The views and opinions of authors expressed herein do not necessarily state or reflect those of the United States Government or any agency thereof. 


\section{DISCLAIMER}

Portions of this document may be illegible in electronic image products. Images are produced from the best available original document. 
"Research sponsored by the U.S. Department of Energy, Fossil Energy Advanced Research and

Technology Development Materials Program, DOE/FE AA 151010 0, Work Breakdown Structure

Element OSU-2"

\title{
PACK CEMENTATION DIFFUSION COATINGS FOR Fe-BASE ALLOYS: FINAL REPORT
}

\author{
Robert A. Rapp, P.I. \\ Department of Materials Science and Engineering \\ The Ohio State University \\ Columbus, $\mathrm{OH} 43210$
}

February 9, 1995

\begin{abstract}
With the aid of computer-assisted calculations of the equilibrium vapor pressures in halide-activated cementation packs, processing conditions have been identified and experimentally verified for the codeposition of two or more alloying elements in a diffusion coating on a variety of steels. The Cr-Si ferrite layers have proven to be very resistant to high temperature cyclic oxidation and to pitting in aqueous solutions. The process has been patented, and is being transfered for industrial application, e.g. for water walls of utility boilers, etc. In the proposed extension of this project, the use of mixed pure metal powders in the pack will be extended to achieve similar ferrite $\mathrm{Fe}-\mathrm{Cr}$-Al coatings with excellent oxidation resistance, with the eventual transfer of the technology to industry.

In other recent studies, Ni-base alloy rods were aluminized by the halideactivated pack cementation process to bring their average composition to that for the ORNL-developed $\mathrm{NizAl}$, for use as a welding rod. A similar effort to develop a welding rod for the ORNL Fe3Al alloy did not yield reproducible coating compositions or growth kinetics. The continued effort to produce Duriron-type (Fe-18Si-5 $\mathrm{Cr}$ ) coatings on steels was not successful. Literature for the intrinsic diffusion coefficients suggests that this task cannot be achieved.
\end{abstract}

\section{INTRODUCTION}

Carbon steels or low alloy steels have served as the workhorse material in the construction of utility boilers, heat exchangers and other power generation installations. However, these steels suffer from corrosion attack in 
the forms of oxidation, sulfidation, and deposition corrosion in these applications. In particular, sulfidation, resulting from the presence of sulfur in low grade fuel, shortens the service life of these structures considerably. High alloy steels (e.g., stainless steels and nickel-base alloys) may survive in these environments, but the associated cost and susceptibility to stress corrosion cracking (SCC) have made these alloys unlikely choices for the major materials of construction for these applications.

Appropriate coatings, applied to carbon or low alloys steels, have long been sought as a means to combat these corrosion problems. Physical vapor deposition, chemical vapor deposition, thermal spray and plasma spray have various advantages and disadvantages. The associated high costs for lowpressure vapor deposition equipment limits its acceptability for large scale application. Spraying methods constitute a line-of-sight technology, which makes them impractical to protect certain geometries, such as the inside walls of heat exchanger tubing. Also, some spray coatings suffer oxidation, high porosity and poor adhesion to the substrate material, leaving them particularly vulnerable to corrosion attack.

A variety of pack cementation diffusion coatings have been used in the aerospace, chemical, and utility industries for about 75 years. These coatings can be inexpensively produced, they are strongly adherent to the substrate, and they are rather versatile in terms of enriching an alloying element at the surface. In fact, the long history of these diffusion coatings gives them a psychological handicap, as they may not be considered "high tech" or "trendy", and decades of occasional inadequate or shoddy application by various industrial shops may have created an unfavorable general reputation for the process. Furthermore, in the past, the pack cementation process was only practiced to add a single element to the substrate; this restriction has limited the ability of the coating to protect the workpiece from a variety of corrosion conditions.

Often, the best corrosion protection is provided by an enrichment at the surface of two or more beneficial alloying elements, which can.produce a very favorable "synergistic effect" in corrosion protection. Sequential diffusion coating of two or more elements on carbon steels and low alloy steels can be done in industry; however, the additional (labor-intensive) furnace runs and the resulting irregular concentration profiles do not make this practice attractive. So to modernize and improve the practice of halide-activated pack cementation coatings, a means was needed to codeposit two or more elements 
simultaneously in the proper concentrations. But such a process faces an inherent difficulty analogous to the electroplating of an alloy, where different elements generally exhibit greatly differing standard half-cell reduction potentials. As shown in our research, the analogous difficulty in codepositing elements by pack cementation is the greatly differing standard Gibbs energies of formation of the various volatile halides for the different metallic components of interest.

The principal goal of the DOE-sponsored research of this project was to provide a much better scientific understanding for the halide-activated pack cementation process, which could lead to the controlled coating of various steels with two or more alloying elements in one thermal process step. As detailed in the following, this approach has achieved significant success and has led to the development of a number of different coatings with superior hightemperature and aqueous corrosion resistance in laboratory (and some industrial) testing. Some such processing successes are currently being transferred for application by industry, and others are under consideration.

\section{PREVIOUS PROCESSING PROGRESS}

Research conducted at The Ohio State University (OSU) over the past 10 years has focused on producing pack cementation diffusion coatings with the deposition of multiple alloying elements during a single furnace run. This "codeposition" has been successful in depositing Cr-Al, Cr-Si, Cr-Si-V, Cr-SiCe coatings on low-carbon steels, $\mathrm{Cr}$-Al on several different austenitic steels, $\mathrm{Al}$ and $\mathrm{Al}-\mathrm{B}$ to transform $\mathrm{Fe} 3 \mathrm{Al}$ to $\mathrm{FeAl}$, and $\mathrm{Cr}-\mathrm{Al}-\mathrm{RE}$ (RE=reactive element) coatings on nickel-base superalloys (Navy support). Also codeposition has been achieved for the formation of B-modified and Ge-doped silicide coatings on $\mathrm{Ti}, \mathrm{Ti}-\mathrm{Al}-\mathrm{Nb}$, and $\mathrm{Nb}-\mathrm{Al}-\mathrm{Ti}$ alloys, and on $\mathrm{Mo}$ (Air Force and Navy support). Through the latter studies, a simple means for the absolute avoidance of lowtemperature $\left(500^{\circ} \mathrm{C}\right)$ "pesting" of $\mathrm{MoSi}_{2}$ was discovered. These successes are listed here only briefly, because they have been reported in detail in previous DOE reports, and have been published in the open scientific literature. Furthermore, a US patent No. 5364659 was recently granted to M. A. Harper and R. A. Rapp at OSU for "Codeposition of Chromium- and Silicon-Diffusion Coatings in Fe-Base Alloys Using Pack Cementation". Babcock and Wilcox (B $\& W)$ cooperated with OSU in submitting the patent application, and is 
presently arbitrating an exclusive license for this technology.

\section{RECENT PROCESSING PROGRESS}

The early stages of this codeposition technology have relied on the use of previously manufactured masteralloy powders which are relatively expensive. By the use of a masteralloy in the pack, the thermodynamic activity of the normally favored element could be reduced, such that with the proper choice of halide actvator salt and process temperature, codeposition, e.g. of $\mathrm{Cr}$ Si or Cr-Al into steels, became possible. But more recently, this DOEsponsored project has focused its effort in reducing the material cost, optimizing the diffusion process, understanding further the high temperature gas chemistry, and interacting with industry. For example: 1) The "common component effect" has been elucidated, which provides a basis for an effective choice of the halide activators in the cementation pack. 2) The costly masteralloys used in initial pack chemistries have been eliminated; instead, inexpensive elemental powders are currently used in most cementation packs. These should also be better suited to rejuvenation in an industrial process. 3) By optimizing the activator(s), the coating time has been shortened to reduce the required energy input for the coating process, the extent of decarburization of the steel has been minimized, and the formation of the undesirable blocking chromium carbide layer on carbon-containing steels has been avoided. 4) Numerous trial runs have been conducted in response to inquiries from industry. 5) Extensive higtemperature and aqueous corrosion tests have been conducted in the laboratory. 6) The important results (except those withheld for patent reasons) have been submitted for publication in the open literature. In the following, some brief accounts are given of recent progress (last two years) for the various project tasks.

\section{Thermodynamic Analyses; the "Common Component Effect"}

After the introduction by Mark Harper of the combined use of a chloride plus a fluoride salt to achieve codeposition of $\mathrm{Cr}$ and $\mathrm{Si}$ into steels, a more general analysis and understanding of the use of dual activators seemed to be needed. As part of a Senior Project, Miss Ning $\mathrm{He}$ and Dr. Ge Wang cooperated to run numerous different SOLGASMIX-type computer-assisted 
calculations of the equilibrium partial pressures for packs containing pure $\mathrm{Cr}$ and pure Si powders with various combinations of activators: single salt, fluoride and chloride salts with a common cation, and fluoride and chloride salts with different cations. Table I shows the results of these calculations. While Table $\mathrm{I}$ is rather detailed, so that close inspection is required, the conditions (activators) suitable for the codeposition of $\mathrm{Cr}$ and $\mathrm{Si}$ have been identified in this way, and these predictions have been verified experimentally.

Figure 1 presents a schematic illustration of the processing scheme required in codepositing $\mathrm{Cr}+\mathrm{Si}$ so that an enriched ferrite surface layer can be grown without the formation of a blocking $\mathrm{Cr}$ carbide surface layer. In short, the ferrite-stabilizing Si must be transported to the surface at a low temperature, e.g. $830^{\circ} \mathrm{C}$, such that the carbon in the steel is rejected into the austenite core, before the $\mathrm{CrCl}_{2}$ vapors reach a sufficient vapor pressure to form $\mathrm{Cr}_{23} \mathrm{C}_{6}$ at a higher temperature. Once the ferrite case has been initiated, the inward rejection of carbon in front of the growing ferrite permits the addition of $\mathrm{Cr}$ solute to the ferrite layer without carbide formation. A similar scheme is applicable for the codeposition of $\mathrm{Cr}+\mathrm{Al}$, which study is proposed for the extension of the existing project. The theory about the "common component effect" and its application to the codeposition of $\mathrm{Cr}$-Si was presented as an invited talk at a Materials Chemistry Conference in Vienna, and the corresponding publication has been submitted to the journal High Temperature Science. In fact, the $\mathrm{Cr}-\mathrm{Si}$ codeposition into steels has now been achieved by the use of pure powders of $\mathrm{Cr}$ and $\mathrm{Si}$, instead of the earlier $\mathrm{Cr}$-Si masteralloy technology, and this result is the subject of a second $B \& W$ - prepared submission to the US patent office. For this reason, the details of the pack composition and processing procedure are not presented here.

\section{Aqueous Corrosion Resistance of Cr-Si-RE Coatings on Steels}

As the subject for a recently completed MS thesis by Miss Endang Pangestuti, an Indonesian student whose University expenses were paid by the oil company which employs her, pack cementation coatings with compositions on the order of $35 \mathrm{Cr}-4 \mathrm{Si}$ (and with or without a small concentration of either cerium or vanadium) were tested by scanning potentiometry in laboratorysimulated seawater. The coatings were deposited onto both 304 and 316 austenitic steels, as well as interstitial-free and low-carbon steels. Again the 
pack contained a mixture of elemental $\mathrm{Cr}$ and $\mathrm{Si}$ powders to produce the $\mathrm{Cr}-\mathrm{Si}$, $\mathrm{Cr}-\mathrm{Si}-\mathrm{Ce}$ and $\mathrm{Cr}$-Si-V coatings. Figure 2 shows anodic polarization curves for the coatings tested in a $0.6 \mathrm{M} \mathrm{NaCl} / 0.1 \mathrm{M} \mathrm{Na}_{2} \mathrm{SO}_{4}$ solution at room temperature.

The additions of $\mathrm{Ce}$ and $\mathrm{V}$ to the $\mathrm{Cr}$-Si coatings were found to provide important improvements in the pitting resistance, i.e. extension of the passive plateau to higher oxidizing potentials and reduction of the passive current density. Even for applications in high temperature fossil fuel systems, e.g. coal gasification units, aqueous corrosion resistance is important in resisting attack by hydrolyzed deposits during downtime. The results of this MS thesis research have been submitted for publication in the journal Corrosion.

\section{Pack Cementation Coatings to Form Welding Rods for NiAl and FeAl}

This was the MS thesis topic for the Chris McVay. Because of their inadequate fabricability to accomplish wire drawing, the structural alloys $\mathrm{Ni}_{3} \mathrm{Al}$ and $\mathrm{Fe} 3 \mathrm{Al}$ developed principally at ORNL required the creation of welding rods by another means. In fact, these intermetallic phases each also contain a number of other alloying elements to optimize their properties. In this research, an attempt was made to aluminize wires of the Ni-base and Fe-base alloy compositions corresponding to the ORNL-developed $\mathrm{Ni}_{3} \mathrm{Al}$ and $\mathrm{Fe} 3 \mathrm{Al}$ materials, except that the wires were low, or devoid, of Al. Then the goal was to deposit coatings sufficiently rich in Al so that the average compositions corresponded to those for the intermetallic phases. For the Ni-base alloy, an external coating of $\mathrm{Ni}_{2} \mathrm{Al}_{3}$ was grown. For this system, sets of conditions (pack composition, temperature, and times) were found to achieve the goal. Figure 3 presents the coating microstructure, and Fig. 4 shows the growth kinetics to achieve the desired average composition for the Ni3Al phase. As a most favorable aspect for the growth of this coating, the $\mathrm{Ni} 3 \mathrm{Al}$ grew dominantly by the inward diffusion of Al, so that the resulting layer did not entrap pack particles. A paper describing this research has been submitted for publication to Scripta Met. Mater.

The analogous problem for coating the Fe-base alloy was more difficult, as the required $\mathrm{Fe}_{2} \mathrm{Al}_{3}$ coating phase grew by dominant outward diffusion of Fe. In that case, a coating free of pack entrapment can only be grown by an "above pack" arrangement. For the available time and resources, a sufficiently 
controlled coating process could not be achieved. Chris McVay has completed his MS degree and now works for Allegheny-Ludlum.

\section{The Silicide Coating of Steels to the FezSi (Duriron) Composition}

The Fe3Si composition, especially when alloyed with about 4-6 wt.\% $\mathrm{Cr}$, constitutes the metallic composition with the best resistance to inorganic acids such as nitric and sulfuric acids. The corresponding commercial alloy Duriron is brittle and can only be fabricated by casting. Obviously, a Fe3Si diffusion coating on a steel with more ductility and toughness would find numerous important applications, an opportunity that has been obvious to researchers around the world for at least 50 years. However, for reasons that have not been obvious previously, past research has not been able to grow a dense diffusion coating of Fe3Si on iron. This search for the "Holy Grail" of coatings became the MS thesis for Ted Cruise. Although considerable progress was made, the desired coating process was not achieved. However, the experiments clearly pointed out that significant coating growth occurred by outward Fe diffusion, so that pack pickup was unavoidable unless an "above pack" arrangement was used. According to the limited literature on interdiffusion in the Fe-Si system, the magnitudes for the intrinsic diffusion coefficients for $\mathrm{Fe}$ and for Si cross in the range of composition from pure $\mathrm{Fe}$ to $\mathrm{Fe} 3 \mathrm{Si}$, as shown in Fig. 5. Since in the diffusional growth of $\mathrm{Fe}_{3} \mathrm{Si}$ on $\mathrm{Fe}$, vacancies diffuse in the same direction as the component with the lower intrinsic diffusion coefficient, in the Fe-Si system, the vacancies in growing $\mathrm{Fe}_{3} \mathrm{Si}$ flow from opposite directions to the $\mathrm{Fe}-10 \mathrm{Si}$ composition, a circumstance which inherently generates voids and a porous coating. The experiments of Ted Cruise could not uncover any halide activator which would avoid the inherent porosity. However, siliciding with some fluoride activators did create a $\mathrm{Si}$ surface composition higher than $\mathrm{Fe} 3 \mathrm{Si}$, a previously unattainable result. At this time, there is considerable doubt that the growth of an FezSi layer on steels can ever be achieved, and continuation of this task is not proposed.

\section{PROJECT HISTORY}

This project was initiated in November 1987, and through February 28 , 1995 , a total of $\$ 661,326$ has been budgeted for this research. The project has 
supported the research of 6 MS students (Ed Naylor, Denis O'Connell, Fred Geib, Mingang Zhu, Ted Cruise and Chris McVay), 2 PhD students (David Miller and Mark Harper), and 4 Post-Doc researchers (Patrick Choquet, Ge Wang, Xiao Ru Wan, and Yrong $\mathrm{He}$ ). A list of publications in the open literature follows; many presentations at many conferences were made, but such an accounting list has not been made. In addition, one patent (US 5364659) has been granted, and one other is pending, and one further OSU disclosure has been submitted.

\section{Project Publications}

D. M. Miller, S.C. Kung, S.D. Scarberry and R.A. Rapp, "Simultaneous Chromizing-Aluminizing Coating of Austenitic Stainless Steels", Oxid. Metals, 29. (1988) 239; ibid, Thermochemistry of Alloys NATO-ASI Series, C286, H. Brodowsky and H.J. Schaller, Eds., (1987) 547.

R. A. Rapp, "Pack Cementation Coating of Steel for High Temperature Applications", paper 131, Corrosion 88, NACE.

V. A. Ravi, P. Choquet, and R.A. Rapp, "Thermodynamics of Simultaneous Chromizing-Aluminizing of Alloys in Halide-Activated Cementation Packs", MRS International Meeting on Advanced Materials, Vol. 4. Tokyo (1989), pp. 483-500.

V. A. Ravi, P. Choquet and R. A. Rapp, "Chromizing-Aluminizing Coating of $\mathrm{Ni}$ - and Fe-Base Alloys by the Pack Cementation Technique", exidation of High Temperature Intermetallics, T. Grobstein annd J. Doychak, eds., TMS, Warrendale, PA, pp.127-145.

P.A. Choquet, M.A. Harper, and R.A. Rapp, "Chromizing-Aluminizing and Chromizing-Siliconizing Coating of a Ferritic Steel", Proceedings of the 7th European Conference on Chemical Deposits from a Gas Phase, Perpignan, France, June 1989.

P.A. Choquet, E.R. Naylor and R.A. Rapp, "Simultaneous Chromizing and Aluminizing of Iron-Base Alloys", Materials Science and Engineering, A121, (1989) pp. 413-418.

R.A. Rapp, "Pack Cementation Coatings of Steels for Fossil Fuel Environments", Corrosion 1989, NACE, paper \#532.

M.A. Harper amd R. A. Rapp, "Codeposition of Chromium and Silicon in Diffusion Coatings for Iron-Base Alloys Using Pack Cementation" Fourth International Conference on Surface Modification Technologies, Paris, 1990. 
M.A. Harper and R. A. Rapp, "Chromized-Siliconized Diffusion Coatings for Iron-Base Alloys by Pack Cementation", Paper \#66, Corrosion 91, NACE 1991; ibid Materials Performance, Sept. (1991) pp.41-44.

M.A.Harper and R. A. Rapp, "Chromized-Siliconized Pack Cementation Diffusion Coatings for Heat-Resistant Alloys", in Heat-Resistant Materials, $\mathrm{K}$. Natesan and D.J. Tilack, Eds., ASM Internat., (1991), pp. 379-86.

F.D. Geib and R.A. Rapp, "Diffusion Coatings for Iron Aluminide FezAl by Halide-Activated Pack Cementation", Processing and Manufacturing of Advanced Materials for High Temperature Applications, V.A. Ravi and T.S. Srivatsan, Eds., TMS Warrendale, PA, pp. 347-60.

R.A. Rapp, "Fundamental Aspects of High-Temperature Corrosion", J. Phys. IV, Colloque C9, 3, Dec. (1993) pp. 1-15.

M.A. Harper and R.A. Rapp, "Codeposited Chromium and Silicon Diffusion Coatings for Fe-Base Alloys Via Pack Cementation", Oxid. Metals, Vol. 42, Nos. 3/4, (1994) pp. 303-333.

R.A. Rapp, "The Codeposition of Elements in Diffusion Coatings by the Pack Cementation Method", Proceedings of International Workshop on Gasifiers", Petten, Netherlands, June 1993; Materials at High Temperatures, 11, (1993) pp. 181-4.

F.D. Geib and R.A. Rapp, "Simultaneous Chromizing-Aluminizing Coating of Low Alloy Steels by a Halide-Activated Pack Cementation Process", Oxid. Metals, 40, (1993) pp.213-28.

X. Wan, G. Wang, and R.A. Rapp, "Resistance to Aqueous Corrosion of Steels Protected by a Cr-Si Diffusion Coating", Proceedings of International Corrosion Congress, Sept. 1993, Vol. 1, pp. 353-69, NACE, Houston, TX..

N. He, G. Wang, and R.A. Rapp, "The Common Component Effect in Multiphase, Multicomponent Equilibria", submitted for publication to High Temperature Science, (1994).

C. McVay and R.A. Rapp, "Diffusion Aluminizing Coatings to Produce $\mathrm{Ni}$ Al Alloy Welding Rods", submitted for publication to Scripta Met \& Mater. Oct. (1994).

E. Pangestuti, G. Wang, and R.A. Rapp, "Aqueous Corrosion Resistance of Cr-Si Diffusion Coatings", submitted for publication to Corrosion. 


\section{HONORS AND AWARDS}

During this project, a number of Honors and Awards were received by project participants:

Mark Harper:

TMS Graduate Student Paper Award

BFGoodrich Collegiate Inventor's Award (one of 3 in USA), 1992

Fulbright Scholarship to NS Wales, Australia 1992

Morris Cohen Outstanding Graduate Student Award of Corrosion

Division of the Electrochemical Society, 1992

SAMPE Outstanding Graduate Student Award, 1991

Robert A. Rapp:

Fellow, The Electrochemical Soc. 1993

Fellow, NACE International, 1994

Distinguished Engineering Alumnus, Purdue University, 1988

National Academy of Engineering 1988

University Professor, The Ohio State University, 1989

Outstanding Achievement Award, High Temperature Materials

Div., The Electrochemical Soc., (1990)

Membe d'Honneur, Societe Francaise de Metallurgie et de Materiaux, 1990

Acta/Scripta Metallurgica Lecturer, 1991-93

Lumley Research Award, OSU College of Engineering 1991

BFGoodrich Collegiate Inventor's Awards (one of three annual awards in USA), with student Robert Bianco, 1991; with student Mark Harper, 1992

Ulrick R. Evans Award, British Corrosion Institute, 1992

Chevalier dans l'ordre des Palmes academiques, Ministere de l'Education et de la Culture Francaise, 1993 


\section{PROPOSED RESEARCH}

TASK 1: The use of elemental $\mathrm{Cr}$ and $\mathrm{Al}$ powders to produce $\mathrm{Cr}-\mathrm{Al}$ coatings on carbon-containing steels, to thereby gain their excellent oxidation or sulfidation behavior, has only recently begun. The growth of very protective coatings using $\mathrm{Cr}$-Al masteralloys was achieved earlier in the project by Fred Geib. More recently, based on the success in the codeposition of $\mathrm{Cr}$-Si using pure metal powders, some preliminary coatings for steel using pure $\mathrm{Cr}$ and pure Al powders have been demonstrated. As shown in Fig. 6, the cyclic oxidation results for IF-iron coated by $\mathrm{Cr}$-Al-Ce codeposition show that a proper $20 \mathrm{Cr}-4 \mathrm{Al}$ coating is superior in cyclic oxidation resistance to commercial Kanthal steel at $900 \mathrm{C}$. In environments where high temperature oxidation/sulfidation corrosion is important, Al-containing coatings have a very distinctive advantage over other coating compositions, as a very protective $\mathrm{Al}_{2} \mathrm{O}_{3}$ film isolates sulfur from the substrate. Figure 7 presents the cyclic oxidation kinetics for other $\mathrm{Cr}$-Al coatings at $700^{\circ} \mathrm{C}$. (Readers should note the scaling factors for the ordinate and abscissa.) The coated steels were hardly tarnished after 2200 1-hr cycles in air at $700^{\circ} \mathrm{C}$. However, these coatings have not been carefully characterized yet, nor is the experimental window for the process well known. Testing in a hot corrosion environment and in industrial reducing (carburizing/sulfiding) gases is required.

Therefore, as research proposed for the next two years, we will develop an optimal cementation pack for the codeposition of $\mathrm{Cr}$-Al with following characteristics:

1) a pack composition using elemental $\mathrm{Cr}$ and $\mathrm{Al}$ powders

2) a pack with an addition of a reactive element-containing compound

3) a pack with the optimum choice of fluoride-chloride activator(s).

We will identify a thermal treatment to produce the RE-doped $\mathrm{Cr}$-Al coating with the aforementioned pack composition, this process will produce a surface composition at least comparable to that of $T 406$ stainless steels, i.e., $>13 \% \mathrm{Cr}$ and $>3 \% \mathrm{Al}$. This composition is known to provide excellent high-temperature 
oxidation resistance and adequate sulfidation resistance to $850 \mathrm{C}$. At the end of this project, OSU will provide the necessary assistance to transfer the technology to an industrial pack cementation coating shop. Discussions toward this goal have already commenced with ABB.

TASK 2: At the end of the this project period, we deposited preliminary Ge-doped silicide diffusion coatings for the ORNL-developed $\mathrm{Cr}$-Nb alloy. From a mixture of pure $\mathrm{Si}$ and $\mathrm{Ge}$ powders and the $\mathrm{NaF}$ activator, at a temperature of $1050^{\circ} \mathrm{C}$, an inward grown $\mathrm{CrSi2}$-base coating was produced on the alloy. However, the preliminary runs did not achieve sufficient $\mathrm{Ge}$ solute in the $\mathrm{CrSi}_{2}$, so that excellent oxidation resistance cannot be expected. Oxidation testing by Dr. P. Tortorelli at ORNL is currently underway. From our considerable experience in siliciding pure $\mathrm{Ti}, \mathrm{Mo}, \mathrm{Ti}-\mathrm{Al}-\mathrm{Nb}$, and $\mathrm{Nb}-\mathrm{Al}-\mathrm{Ti}$ alloys, the necessary process variations to improve the coating on the $\mathrm{Cr}-\mathrm{Nb}$ alloy are apparent. In the extension of the project, this improved coating will be optimized and tested.

\section{PERSONNEL and FACILITIES}

After continued research in the development of the codeposition of elements by the pack cementation process for a decade, the research group of Professor Rapp is well equipped with high-temperature processing furnaces, the necessary computer software, the equipment required to establish the coating resistance to oxidizing and corroding environments, and the needed characterization instruments. For the proposed renewal period, Professor Rapp would advise the research of one Post-Doctoral researcher and one Graduate Assistant for a period of two years. The requisite budget estimate for $\$ 238,843$ for the period $3 / 1 / 95$ to $2 / 28 / 97$ has been submitted separately to DOE-ORNL. 


\begin{tabular}{|c|c|c|c|c|c|c|c|c|}
\hline \multicolumn{9}{|c|}{ Table I } \\
\hline \multirow[t]{2}{*}{ Single Salt } & $\mathrm{P}(\mathrm{CrCl} 2)$ & $P($ SiF2) & $\mathrm{P}(\mathrm{SiCl} 2)$ & $\mathrm{P}(\mathrm{Cl})^{*}$ & $P(F)^{*}$ & $P(M 1)^{* \star}$ & $P(M 2)^{\star \star *}$ & Comments \\
\hline & & & & & & & & \\
\hline $\mathrm{NaCl}$ & $3.66 \mathrm{E}-05$ & & $2.66 \mathrm{E}-05$ & $1.20 \mathrm{E}-08$ & & $\mathrm{Na}: 1.28 \mathrm{E}-4$ & & \\
\hline $\mathrm{NaF}$ & & $8.23 E-05$ & & & $2.76 \mathrm{E}-14$ & Na: $1.86 \mathrm{E}-2$ & & High $P(\mathrm{Na})$ \\
\hline $\mathrm{KCl}$ & $1.68 \mathrm{E}-05$ & & $1.22 \mathrm{E}-05$ & $8.13 E-09$ & & $\mathrm{~K}: 5.83 \mathrm{E}-5$ & & \\
\hline$\overline{k F}$ & & $1.08 \mathrm{E}-04$ & & & $3.17 \mathrm{E}-14$ & $\mathrm{~K}: 3.17 \mathrm{E}-2$ & & High $P(K)$ \\
\hline $\mathrm{MgCl} 2$ & $9.34 \mathrm{E}-05$ & & $6.79 \mathrm{E}-05$ & $1.92 \mathrm{E}-08$ & & $\mathrm{Mg}: 1.49 \mathrm{E}-4$ & & \\
\hline $\mathrm{MgF} 2$ & & $7.46 \mathrm{E}-06$ & & & $8.28 \mathrm{E}-15$ & $\mathrm{Mg}: 1.01 \mathrm{E}-4$ & & \\
\hline $\mathrm{CaCl} 2$ & $7.28 \mathrm{E}-08$ & & $5.29 \mathrm{E}-08$ & $5.36 \mathrm{E}-10$ & & Ca: $1.44 \mathrm{E}-8$ & & \\
\hline \multirow[t]{2}{*}{$\mathrm{CaF2}$} & & $3.84 \mathrm{E}-08$ & & & $5.96 \mathrm{E}-06$ & Ca: $3.75 E-8$ & & \\
\hline & & & & & & & & \\
\hline Two Salts & $\mathrm{P}(\mathrm{CrCl} 2)$ & $\mathrm{P}(\mathrm{SiF} 2)$ & $\mathrm{P}(\mathrm{SiCl} 2)$ & $P(\mathrm{Cl})$ & $P(F)$ & $P(M 1)$ & $P(M 2)$ & Comments \\
\hline \multicolumn{2}{|c|}{ Common Cations } & & & & & & & \\
\hline $\mathrm{NaCl} \& \mathrm{NaF}$ & $1.65 \mathrm{E}-10$ & $8.23 \mathrm{E}-05$ & $1.20 \mathrm{E}-10$ & $2.55 \mathrm{E}-11$ & $2.76 \mathrm{E}-14$ & Na: $1.86 \mathrm{E}-2$ & & $\mathrm{P}(\mathrm{CrCl} 2)$ \\
\hline $\mathrm{KCl} \& \mathrm{KF}$ & $5.66 \mathrm{E}-11$ & $1.08 \mathrm{E}-04$ & $4.11 \mathrm{E}-11$ & $1.49 \mathrm{E}-11$ & $3.17 \mathrm{E}-14$ & $\mathrm{~K}: 3.17 \mathrm{E}-2$ & & $\mathrm{P}(\mathrm{CrCl} 2)$ \\
\hline $\mathrm{MgCl} 2 \& \mathrm{MgF} 2$ & $8.24 \mathrm{E}-05$ & $4.43 \mathrm{E}-06$ & $6.00 \mathrm{E}-05$ & $1.80 \mathrm{E}-08$ & $6.40 \mathrm{E}-15$ & Mg: $1.7 \mathrm{E}-4$ & & Minor Effect \\
\hline $\mathrm{CaCl} 2 \& \mathrm{CaF} 2$ & $4.66 \mathrm{E}-08$ & $6.39 E-08$ & $4.39 \mathrm{E}-08$ & $4.29 \mathrm{E}-10$ & $7.69 \mathrm{E}-16$ & Ca: $2.25 \mathrm{E}-8$ & & \\
\hline Two Salts & $\mathrm{P}(\mathrm{CrCl} 2)$ & & & $P(C l)$ & $P(F)$ & $P(M 1)$ & $P(M 2)$ & Comments \\
\hline \multicolumn{2}{|c|}{ Different Cations } & & 101021 & .10 & (II) & (1) & 18 . & - \\
\hline $\mathrm{NaCl} \& \mathrm{KF}$ & $9.11 \mathrm{E}-11$ & $2.00 \mathrm{E}-04$ & $6.62 \mathrm{E}-11$ & $1.90 \mathrm{E}-11$ & $4.30 \mathrm{E}-14$ & $\mathrm{Na}: 8.09 \mathrm{e}-2$ & $\mathrm{~K}: 2.34 \mathrm{e}-2$ & $K F=0.1$ (mole) \\
\hline $\mathrm{NaCl} \& \mathrm{CaF} 2$ & $4.17 \mathrm{E}-06$ & $1.02 \mathrm{E}-05$ & $3.03 \mathrm{E}-06$ & $4.05 \mathrm{E}-09$ & $9.72 \mathrm{E}-15$ & $\mathrm{Na}: 3.78 \mathrm{e}-4$ & Ca: $1.41 \mathrm{e}-10$ & \\
\hline $\mathrm{KCl} \& \mathrm{NaF}$ & $5.47 \mathrm{E}-10$ & $1.00 \mathrm{E}-04$ & $3.97 \mathrm{E}-10$ & $4.64 \mathrm{E}-11$ & $3.04 \mathrm{E}-14$ & $\mathrm{Na}: 1.69 \mathrm{e}-2$ & $K: 1.02 \mathrm{e}-2$ & High $P(K)$ \\
\hline $\mathrm{KCl} \& \mathrm{MgF} 2$ & $4.75 \mathrm{E}-07$ & $1.18 \mathrm{E}-05$ & $3.45 \mathrm{E}-07$ & 1.37E-09 & $1.04 \mathrm{E}-14$ & $\mathrm{Mg}: 6.35 \mathrm{e}-5$ & $K: 3.46 \mathrm{e}-4$ & \\
\hline $\mathrm{KCl} \& \mathrm{CaF} 2$ & $1.62 \mathrm{E}-06$ & $6.95 \mathrm{E}-06$ & $1.18 \mathrm{E}-06$ & $2.53 E-09$ & $8.02 E-15$ & $\mathrm{Ca}: 2.07 \mathrm{e}-10$ & $K: 1.88 \mathrm{e}-4$ & \\
\hline $\mathrm{MgCl} 2 \& \mathrm{NaF}$ & $8.48 \mathrm{E}-08$ & $6.36 \mathrm{E}-03$ & $6.16 \mathrm{E}-08$ & $5.78 \mathrm{E}-10$ & $5.80 \mathrm{E}-14$ & $M g: 1.64 \mathrm{e}-1$ & $\mathrm{Na}: 8.86 \mathrm{e}-3$ & \\
\hline $\mathrm{CaCl} 2 \& \mathrm{NaF}$ & $6.46 \mathrm{E}-06$ & $8.86 \mathrm{E}-06$ & $4.70 \mathrm{E}-06$ & $5.05 \mathrm{E}-09$ & $9.05 \mathrm{E}-15$ & $\mathrm{Ca}: 1.62 \mathrm{e}-10$ & $\mathrm{Na}: 3.03 \mathrm{e}-4$ & \\
\hline $\mathrm{CaCl} 2 \& \mathrm{KF}$ & $5.66 \mathrm{E}-11$ & $1.08 \mathrm{E}-04$ & $4.11 \mathrm{E}-11$ & $1.49 \mathrm{E}-11$ & $3.67 E-14$ & $\mathrm{Ca}: 1.33 \mathrm{e}-11$ & $\mathrm{~K}: 3.17 \mathrm{e}-2$ & $K F=0.05$ (mole) \\
\hline $\mathrm{CaCl} 2 \& \mathrm{MgF} 2$ & $5.28 \mathrm{E}-06$ & $7.24 \mathrm{E}-06$ & $3.83 \mathrm{E}-06$ & $4.56 \mathrm{E}-09$ & $8.18 \mathrm{E}-15$ & $\mathrm{Ca}: 1.99 \mathrm{e}-10$ & $M g: 1.03 e-4$ & \\
\hline & & & & & & & & \\
\hline
\end{tabular}


Diffusion Coating of Steels

Chromizing

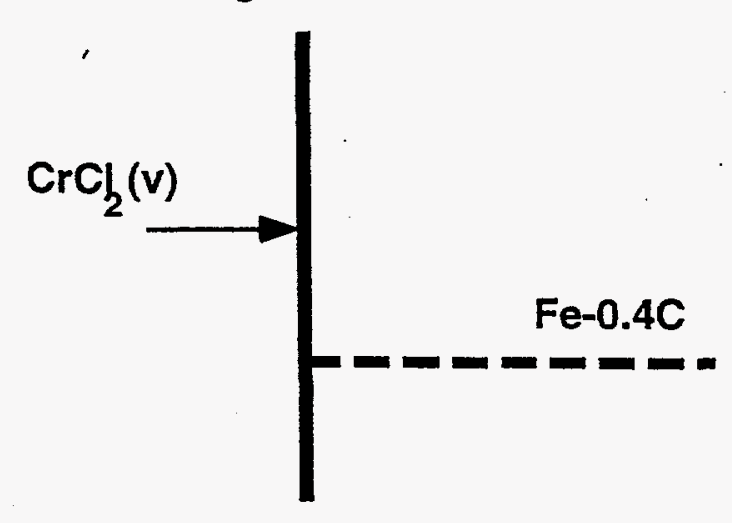

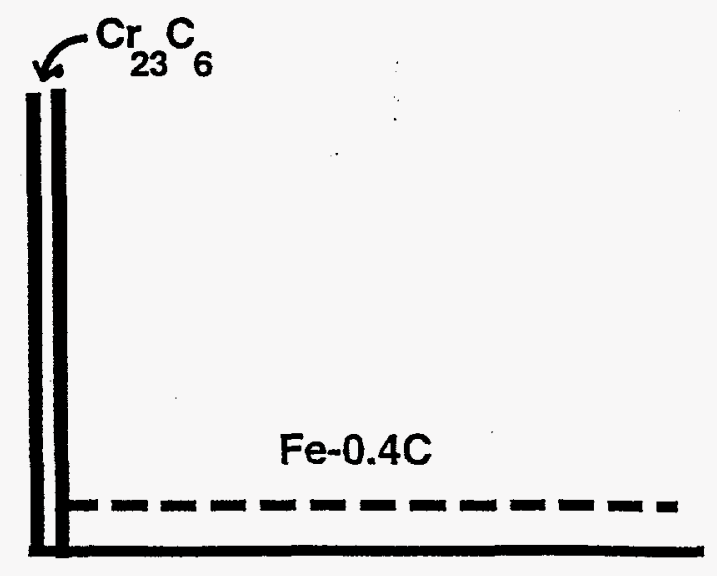

Siliconizing

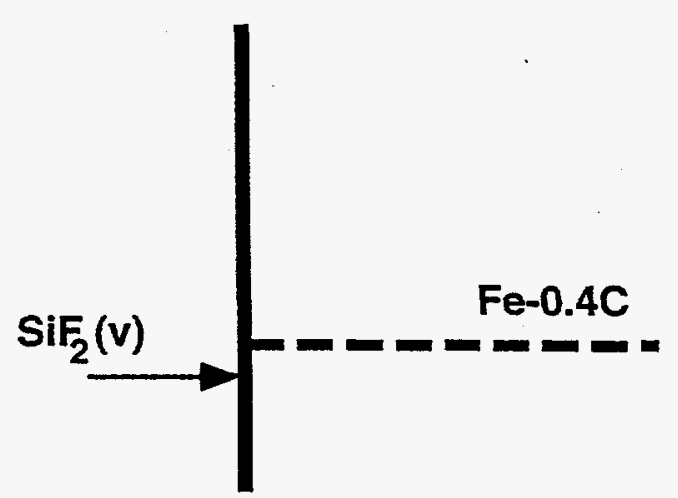

$\alpha$

$\gamma$

4

2.5 Fe- $0.4 \mathrm{C}$

Siliconizing Followed by Chromizing
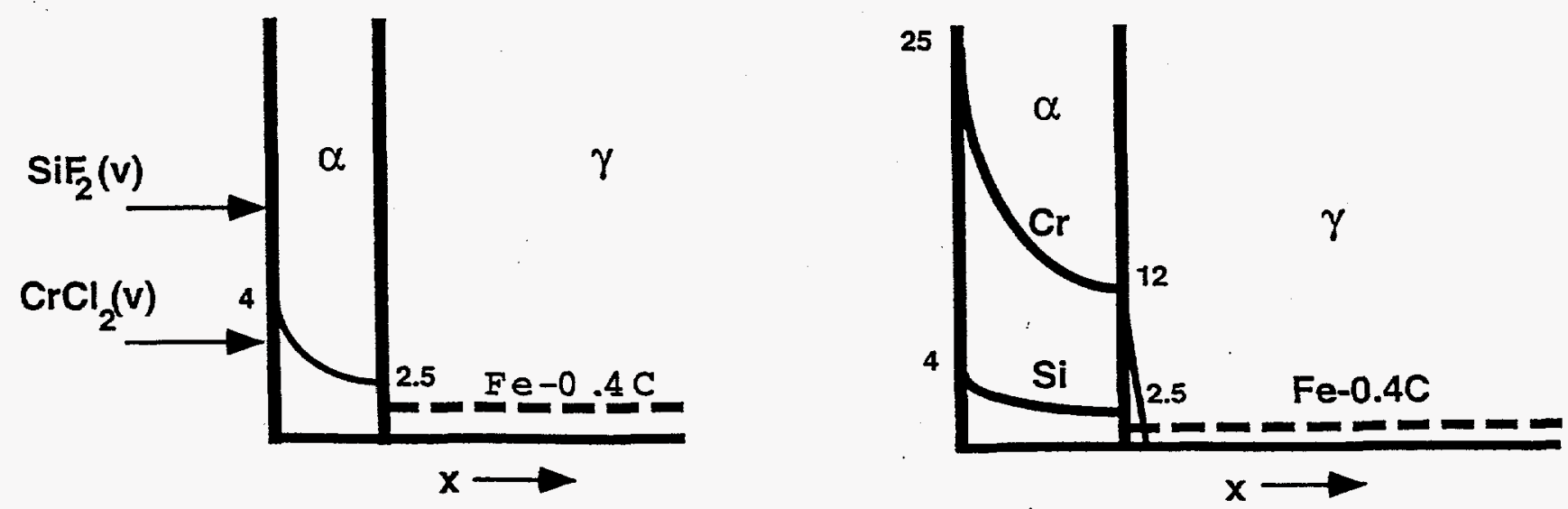

Fig. I Processing Scheme Illustrating Mode for Codeposition of Cr-Si (or CraAl) to Form a Ferrite Case without a Blocking $\mathrm{Cr}$ Carbide 

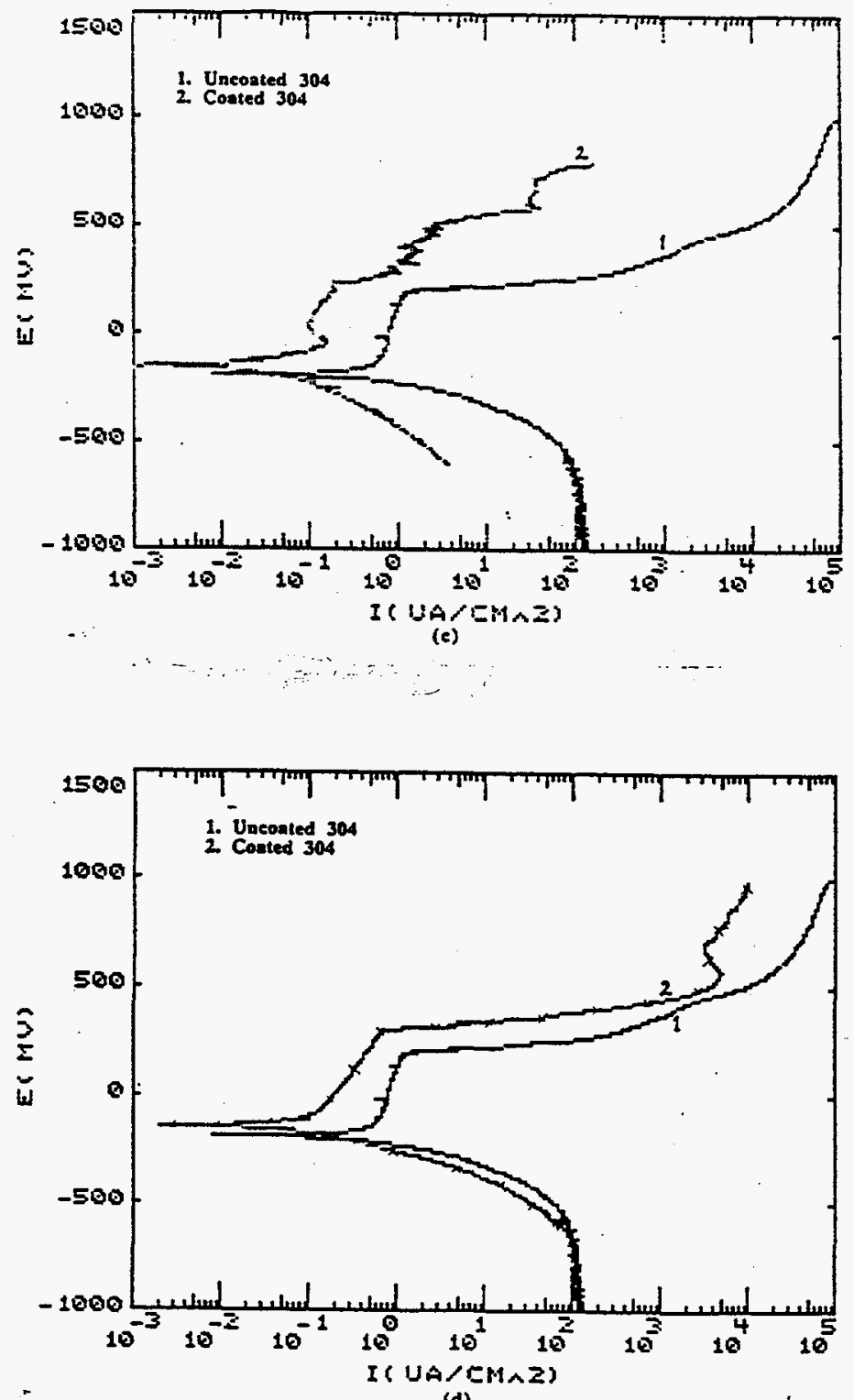

Figure 2. Potentiodynamic Curves for coated 304 coupons with the following surface compositions : (c) $48.9 \mathrm{Cr}-3.67 \mathrm{Si}-0.64 \mathrm{~V}$, and (d) $35.8 \mathrm{Cr}-2.9 \mathrm{Si}$ with $\mathrm{Ce}$ added. 
$\mathrm{Ni}_{2} \mathrm{Al}_{3}$ Matrix

100 microns

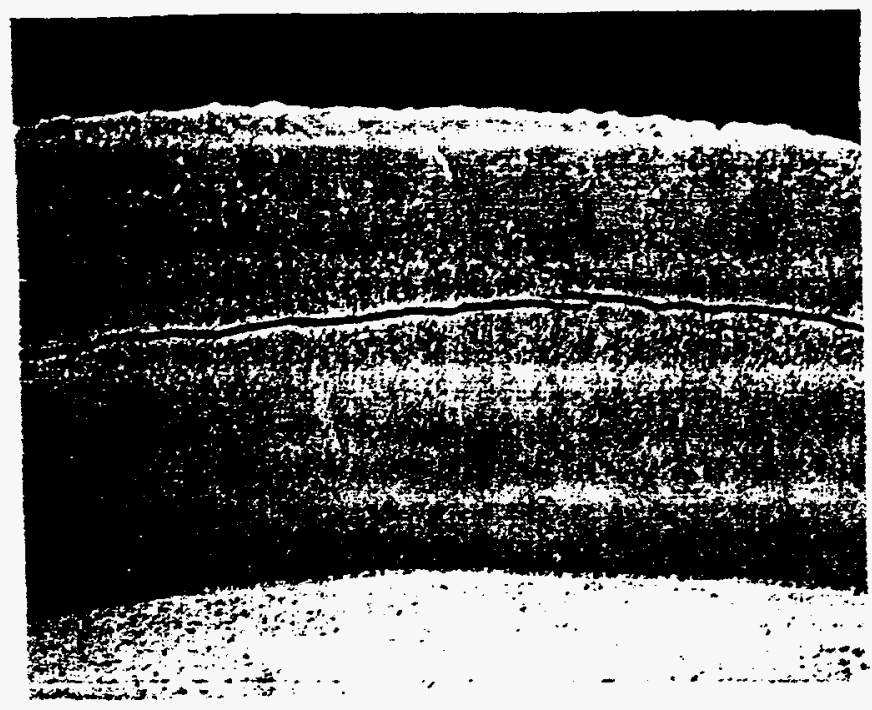

Bakelite

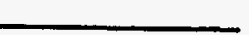

Coating

Substrate

Figure 3 Coating Produced on Ni-base Alloy Substrate at $1000^{\circ} \mathrm{C}$ for $7.8 \mathrm{hr}$. with 30-70 Ni-Al Source and AlF 3 Activator

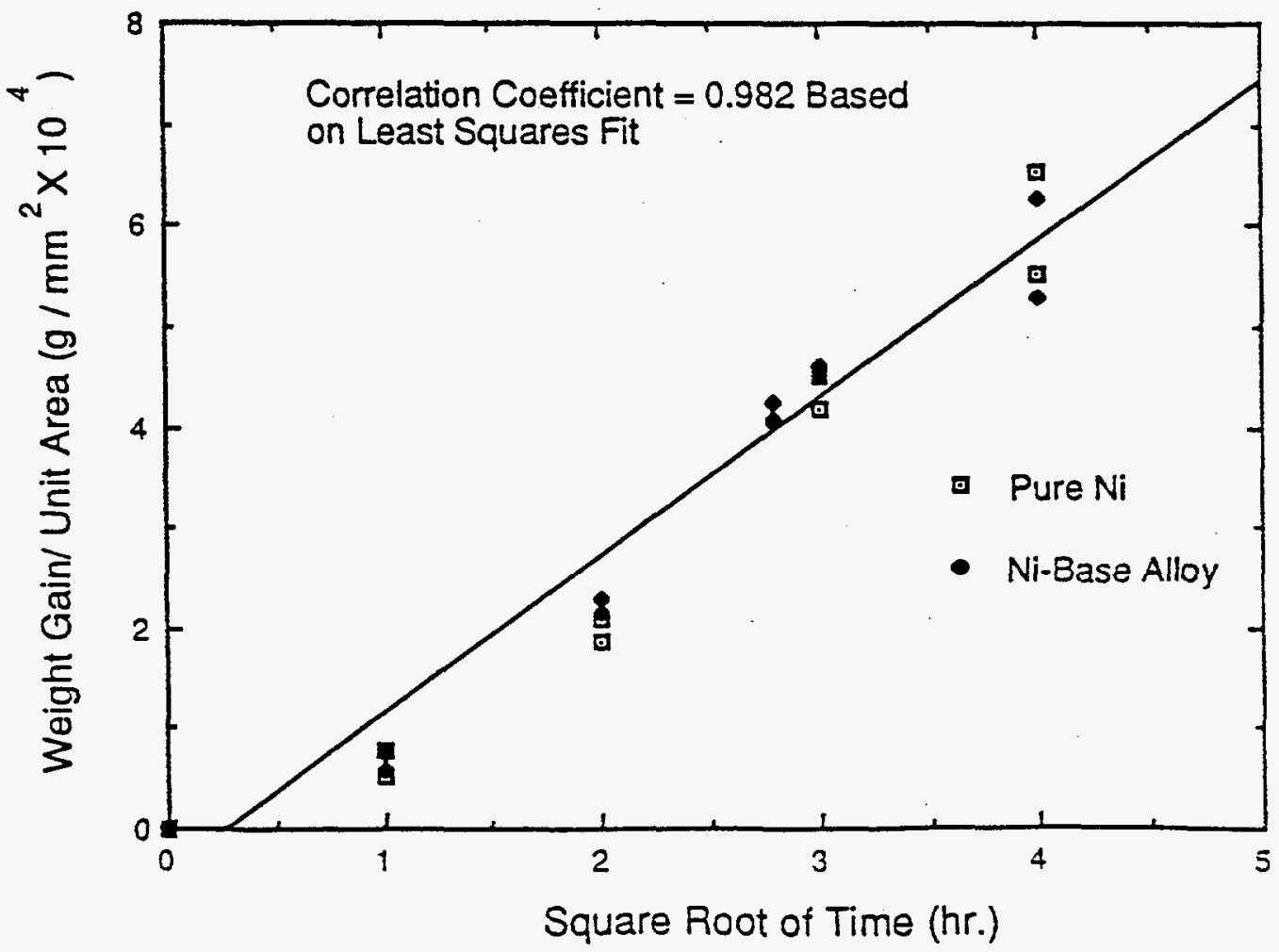

Figure 4 Weight Gain/ Unit Area vs. Square Root of Time for 30:70 Ni-Al, AlF 3 Packs 

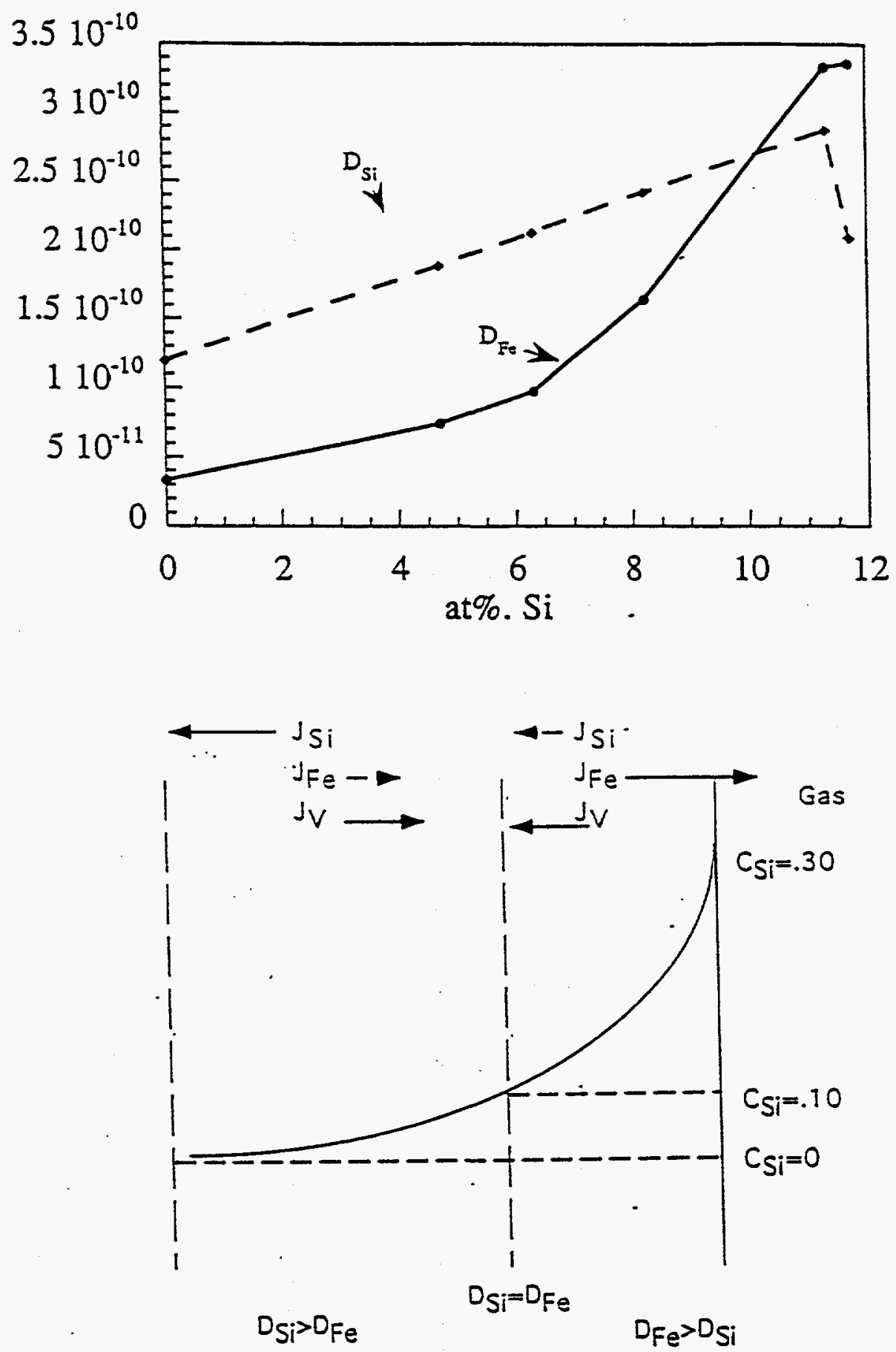

Figure 5 A. Plot in intrinsic diffusion coefficients for $\mathrm{Fe}$ and $\mathrm{Si}$ in Fe-Si alloys

B. Corresponding schematic drawing of diffusion fluxes for the growth of an $\mathrm{Fe} 3 \mathrm{Si}$ layer on pure iron. Vacancies condense at $\mathrm{NSi}=0.10$ composition. 


\section{Cyclic Oxidation at $900 \mathrm{C}$}

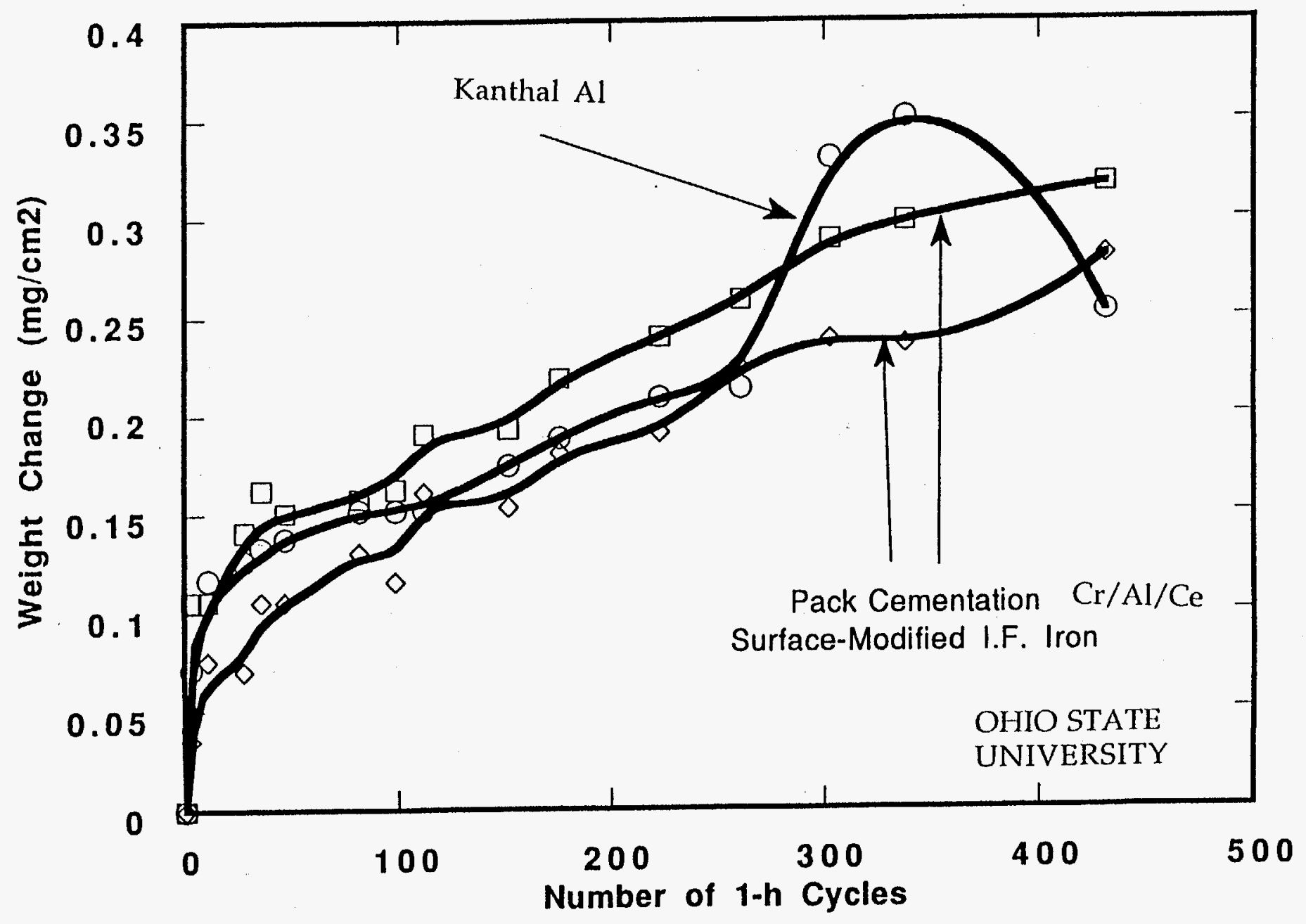

Fig 6. Cyclic oxidation of interstitial-free iron coated with $\mathrm{Cr}$ and $\mathrm{Al}$ at $900^{\circ} \mathrm{C}$. Kanthal Composition : $\mathrm{Fe}-22.5 \mathrm{Cr}-5.5 \mathrm{Al}$ 


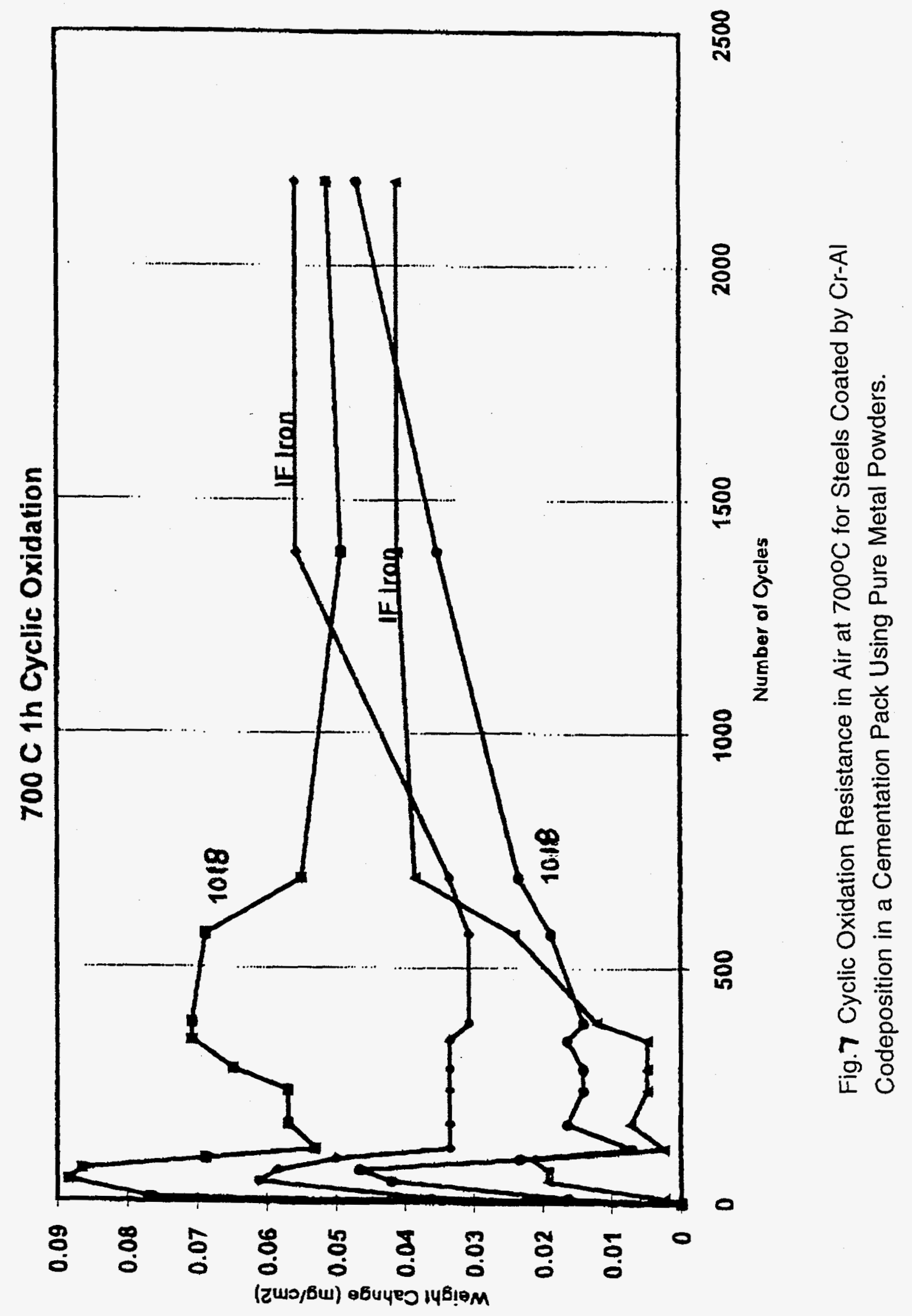


Appendix

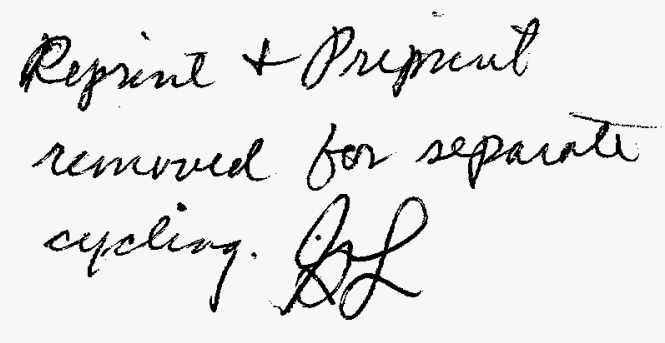




\section{DISTRIBUTION}

AIR PRODUCTS AND CHEMICALS

P.O. Box 538

Allentown, PA 18105

S. W. Dean

ALBERTA RESEARCH COUNCIL

Oil Sands Research Department

P.O. Box 8330, Postal Station F

Edmonton, Alberta

Canada T6H5X2

L. G. S. Gray

ALLISON GAS TURBINE DIVISION

P.O. Box 420

Indianapolis, IN 46206-0420

P. Khandelwal (Speed Code W-5)

R. A. Wenglarz (Speed Code W-16)

AMAX R\&D CENTER

5950 McIntyre Street

Golden, CO 80403

T. B. Cox

ARGONNE NATIONAL LABORATORY

9700 S. Cass Avenue

Argonne, IL 60439

W. A. Ellingson

K. Natesan

ARGONNE NATIONAL

LABORATORY-WEST

P.O. Box 2528

Idaho Falls, ID 83403-2528

S. P. Henslee

AVCO RESEARCH LABORATORY

2.385 Revere Beach Parkway

iverett, MA 02149

R. J. Pollina

BABCOCK \& WILCOX

1562 Beeson St.

Alliance, OH 44601

T. I. Johnson
BABCOCK \& WILCOX

Domestic Fossil Operations

20 South Van Buren Avenue

Barberton, OH 44023

M. Gold

BETHLEHEM STEEL CORPORATION

Homer Research Laboratory

Bethlehem, PA 18016

B. L. Bramfitt

J. M. Chilton

BRITISH COAL CORPORATION

Coal Research Establishment

Stoke Orchard, Cheltenham

Glocestershire, England GL52 4RZ

J. Oakey

CANADA CENTER FOR MINERAL \& ENERGYTECHNOLOGY

568 Booth Street

Ottawa, Ontario

Canada K1A OG1

R. Winston Revie

Mahi Sahoo

COLORADO SCHOOL OF MINES

Department of Metallurgical Engineering

Golden, CO 80401

G. R. Edwards

DOE

DOE OAK RIDGE OPERATIONS

P. O. Box 2008

Building 4500N, MS 6269

Oak Ridge, TN 37831

E. E. Hoffman

DOE

DOE OAK RIDGE OPERATIONS

P. O. Box 2001

Oak Ridge, TN 37831

Assistant Manager for

Energy Research and Development 
DOE

IDAHO OPERATIONS OFFICE

P. O. Box 1625

Idaho Falls, ID 83415

R. B. Loop

DOE

MORGANTOWN ENERGY TECHNOLOGY

CENTER

P.O. Box 880

Morgantown, WV 26505

R. C. Bedick

D. C. Cicero

F. W. Crouse, Jr.

N. T. Holcombe

W. J. Huber

J. E. Notestein

DOE

OFFICE OF FOSSIL ENERGY

Washington, DC 20545

J. P. Carr (FE-72) GTN

DOE

OFFICE OF BASIC ENERGY SCIENCES

Materials Sciences Division

ER-131 GTN

Washington, DC 20545

J. B. Darby

DOE

OFFICE OF SCIENTIFIC AND TECHNICAL INFORMATION

P. O. Box 62

Oak Ridge, TN 37831

For distribution by microfiche as shown in DOE/TIC-4500, Distribution Category: UC-114 (Coal Based Materials and Components)
DOE

PITTSBURGH ENERGY TECHNOLOGY

CENTER

P.O. Box 10940

Pittsburgh, PA 15236

A. L. Baldwin

G. V. McGurl

R. Santore

T. M. Torkos

EC TECHNOLOGIES INC.

3614 Highpoint Drive

San Antonio, TX 78217

D. J. Kenton

ELECTRIC POWER RESEARCH

INSTITUTE

P.O. Box 10412

3412 Hillview Avenue

Palo Alto, CA 94303

W. T. Bakker

J. Stringer

H. Wolk

EUROPEAN COMMUNITIES JOINT

RESEARCH CENTRE

Petten Establishment

P.O. Box 2

1755 ZG Petten

The Netherlands

M. Van de Voorde

FOSTER WHEELER DEVELOPMENT

CORPORATION

Materials Technology Department

John Blizard Research Center

12 Peach Tree Hill Road

Livingston, NJ07039

J. L. Blough

IDAHO NATIONAL ENGINEERING

LABORATORY

P.O. Box 1625

Idaho Falls, ID 83415

A. B. Denison

R. N. Wright 
LAWRENCE LIVERMORE LABORATORY

P.O. BoX 808, L-325

Livermore, CA 94550

W. A. Steele

NATIONAL MATERIALS ADVISORY

BOARD

National Research Council

2101 Constitution Avenue

Washington, DC 20418

K. M. Zwilsky

NEW ENERGY AND INDUSTRIAL

TECHNOLOGY DEVELOPMENT

ORGANIZATION

Sunshine $60 \mathrm{Bldg}$.

P.O. Box 1151, 1-1

Higashi-Ikebukuro 3-chrome

Toshima-Ku, Tokyo, 170

Japan

H. Narita

S. Ueda

OAK RIDGE NATIONAL LABORATORY

P.O. Box 2008

Oak Ridge, TN 37831

P. T. Carlson

N. C. Cole

R. R. Judkins

C. T. Liu

R. A. Lawson (8 copies)

C. G. McKamey

V. K. Sikka

R. W. Swindeman

P. T. Thornton

I. G. Wright

PACIFIC NORTHWEST LABORATORY

P. O. Box 999, K3-59

Battelle Boulevard

Richland, WA 99352

R. N. Johnson

RESEARCH TRIANGLE INSTITUTE

P.O. Box 12194

Research Triangle Park, NC 27709

T. W. Sigmon
SHELL DEVELOPMENT COMPANY

P. O. Box 1380

Houston, TX 77251-1380

L. W. R. Dicks

THE JOHNS HOPKINS UNIVERSITY

Materials Science \& Engineering

Maryland Hall

Baltimore, MD 21218

R. E. Green, Jr.

THE MATERIALS PROPERTIES COUNCIL,
INC.

United Engineering Center

345 E. Forty-Seventh Street

New York, NY 10017

M. Prager

THE TORRINGTON COMPANY

Advanced Technology Center

59 Field Street

Torrington, CT 06790

W. J. Chmura

UNION CARBIDE CORPORATION

Linde Division

P.O. Box 44

175 East Park Drive

Tonawanda, NY 14151-0044

Harry Cheung

UNIVERSITY OF WASHINGTON

Department of Materials Science

and Engineering

101 Wilson, FB-10

Seattle, WA 98195

T. G. Stoebe

UNIVERSITY OF TENNESSEE SPACE

INSTITUTE

Tullahoma, TN 37388

J. W. Muehlhauser 
UNIVERSITY OF TENNESSEE AT

KNOXVILLE

Materials Science and Engineering

Department

Knoxville, TN 37996

P. Liaw

C. D. Lundin

WESTERN RESEARCH INSTITUTE

365 N. 9th Street

P.O. Box 3395

University Station

Laramie, WY 82071

V. K. Sethi

WESTINGHOUSE ELECTRIC

CORPORATION

Research and Development Center

1310 Beulah Road

Pittsburgh, PA 15235

S. C. Singhal 